Jurnal Bisnis dan Manajemen, Volume 22, No. 1, March 2021, p. 40-50

\title{
THE INFLUENCE OF DESTINATION ATTRIBUTES ON TOURISTS' LENGTH OF STAY IN KEBUMEN REGENCY, CENTRAL JAVA
}

\author{
Fajar Aditya Nugroho ${ }^{1}$, Anang Sutono ${ }^{2}$, Tatang Sopian ${ }^{3}$ \\ ${ }^{1,2,3}$ Sekolah Tinggi Pariwisata Bandung, Indonesia
}

\begin{abstract}
UNWTO states that the record of the length of stay of tourists in most tourist destinations in the world tends to be low and decreasing. In line with this issue, Kebumen Regency is recorded to have a low tourist length of average stay duration, which is 0.54 days until the end of 2019. The tourists' length of stay is closely related to the acceptance of the destination expenditure, and an increase in tourist stays can be a solution for Kebumen Regency which is noted to be the poorest district in Central Java. This research is intended to find the level of influence of destination attribute variables on the tourists' length of stay variables. In describing the required attributes, used ten attributes of tourist destinations, namely infrastructure, superstructure, accessibility, activities/ events, local culture, physiography, destination management, service quality, hospitality, and place attachments. In this study, a descriptive method with a quantitative approach is used to obtain a detailed description of the actual conditions of the Kebumen destination attributes and their effect on the length of stay of tourists from the measured sub-variables. The result is found that destination attributes have a significant effect on the tourists' length of stay in Kebumen with a coefficient of determination (magnitude of influence) of $68.8 \%$. The attributes considered in good condition by the respondents are infrastructure, superstructure, accessibility, physiography, destination management, service quality, and hospitality attributes. On the contrary, more intense and comprehensive development is still needed on the activities/ events, local culture, and place attachments attributes.
\end{abstract}

Keywords: Destination Attributes, Tourists’ Length of Stay, Tourism Expenditure Stay

\section{PENGARUH DESTINATION ATTRIBUTES TERHADAP LAMA TINGGAL WISATAWAN DI KABUPATEN KEBUMEN}

\begin{abstract}
ABSTRAK
UNWTO menyatakan bahwa catatan lama tinggal wisatawan di sebagian besar destinasi wisata di dunia cenderung rendah dan mengalami penurunan. Sejalan dengan isu tersebut, Kabupaten Kebumen tercatat memiliki rata-rata lama tinggal wisatawan rendah yakni selama 0,54 hari hingga akhir tahun 2019. Padahal, lama tinggal wisatawan erat kaitannya dengan penerimaan ekonomi destinasi tersebut dan peningkatan lama tinggal wisatawan dapat menjadi solusi bagi Kabupaten Kebumen yang tercatat menjadi kabupaten termiskin di Jawa Tengah. Untuk menjawab persoalan tersebut, maka dilakukan analisis pengaruh variabel destination attributes terhadap variabel lama tinggal wisatawan. Dalam menjabarkan atribut-atribut yang diperlukan maka digunakan 10 atribut destinasi wisata yakni infrastruktur, suprastruktur, aksesibilitas, aktivitas/event, budaya lokal, fisiografi, manajemen destinasi, kualitas pelayanan, hospitality, serta place attachment. Dalam penelitian ini, metode deskriptif dengan pendekatan kuantitatif digunakan untuk memperoleh gambaran secara rinci tentang kondisi aktual atribut destinasi Kebumen dan pengaruhnya terhadap lama menginap wisatawan dari sub variabel yang diukur. Dari hasil analisis dan pembahasan diperoleh temuan bahwa destination attributes berpengaruh positif dan signifikan terhadap lama tinggal wisatawan di Kabupaten Kebumen dengan koefisien determinasi (besaran pengaruh) sebesar 68,8\%. Adapun atribut-atribut yang dianggap berkondisi baik oleh responden ialah atribut infrastruktur, suprastruktur, aksesibilitas, fisiografi, manajemen destinasi, kualitas pelayanan, serta hospitality. Sebaliknya, masih diperlukan pengembangan lebih intens dan terfokus pada atribut aktivitas/ event, budaya lokal, serta place attachment.
\end{abstract}

Kata-kata Kunci: Destination Attributes, Lama Tinggal Wisatawan, Tourism Expenditure

${ }^{2}$ Korespondensi: Dr. Anang Sutono, Associate Professor for Tourism Business Management at Sekolah Tinggi Pariwisata Bandung (Bandung Institute of Tourism). Jln. Dr. Setiabudi No.186, Kota Bandung, Jawa Barat 40141. Email: anang@stp-bandung.ac.id.

Submitted: December 2020, Accepted: March 2021, Published: March 2021

ISSN: 1412 - 3681 (printed), ISSN: 2442 - 4617 (online), Website: http://journal.feb.unpad.ac.id/index.php/jbm 
Jurnal Bisnis dan Manajemen, Volume 22, No. 1, March 2021, p. 40-50

\section{INTRODUCTION}

As a sector that is being prioritized for development and is expected to be Indonesia's main foreign exchange earner, tourism is a strategic matter whose economic impact will have a significant impact on society, especially those around destinations. Tourism concerning the social economy cannot be separated from the existence of tourists who visit and how long they visit. This is due to the assumption that the longer their visit will be the greater their expenditure, which in turn will also increase the income of the surrounding community and the management, and in the end, there will be an increase in aggregate income (Thrane \& Farstad, 2012). However, the issue that is happening globally shows that the length of stay of tourists tends to be low even continues to decline (UNWTO, 2019). This is caused by several things such as trimming travel time between tourist attractions in a destination as a result of improving the quality of infrastructure (Gössling et al., 2018), as well as the tendency to travel multidestination/multi-destination travel trips (MTT) (Santos et al., 2015).

In Indonesia, one of the destinations that have an average record of low tourist length of stay is Kebumen Regency. Kebumen is a regency located in the southern part of Central Java Province. Officially, there are 36 managed tourist attractions in Kebumen with 9 attractions managed by the regional government and 27 others managed by the private sector. The condition of these attractions spread should be able to make tourists want to visit and spend a long time in Kebumen. However, the Head of the Kebumen's government tourism office, Azam Fathoni, M.Si, in the "2018 Kebumen Regency Main Performance Indicator Evaluation (IKU)" explained that the average length of stay of tourists in Kebumen was only 0.51 days or 12.24 hours in 2017 and 0.54 days or around 12.96 hours in 2018. This certainly needs to be noted because the figure is fairly low and the increase was not significant. Moreover, this number is below the average length of stay of Central Java Province tourists which is at 3 days for foreign tourists and 1.5 days for local tourists, launching in the 2019 Pocket Book (Disporapar Jawa Tengah, 2019).

The importance of commitment to increasing the length of stay of tourists in its role as an increase factor in Regional Original Revenue (PAD) of Kebumen Regency is in line with what was stated in RIPPARKAB Kebumen 2017-2025 period. In the document, it was stated that one of the objectives of tourism development in the Kebumen Regency was to improve the economy and empower people through increasing investment in tourism and expanding employment. This becomes vital following the fact that Kebumen Regency is listed as the poorest district in Central Java Province in 2019 with a poverty percentage index of $16.82 \%$ and there are around 201,000 households/ around 700,000 people included in the category of poor people with a monthly income less than $\mathrm{Rp}$. 363,000 according to the Central Java Statistics 
Jurnal Bisnis dan Manajemen, Volume 22, No. 1, March 2021, p. 40-50

Agency (detik.com, 2019). Therefore, it can be assumed that striving to increase the length of stay of tourists in the Kebumen Regency can overcome the problem of poverty.

The fact that Kebumen is only considered a transit point from one area to another. Besides, this study also focuses on examining the effect of destination attributes on the length of stay of tourists, unlike previous studies, which have the aim of determining various factors that can affect the length of stay of tourists in a destination.

According to Jani et al. (in Chahal \& Devi, 2015), the length of stay of tourists is influenced by various things, one of which is the "Destination Attributes" factor. Destination attributes itself is a concept that reviews what a destination can/ has to offer to tourists because tourists tend to consider what the destination has to offer and the potential experience they will receive (Uysal et al., 2012). In contrast, destination attributes are closely related to the length of stay of tourists in a destination. "Tourist destinations comprise of multi-destination trip attributes that include both environmental atmospheric and service attributes which encourage tourists to visit and to stay longer within the destination" (Jani et al., 2009). Destination attributes can encourage tourists to spend more time visiting a destination. Therefore, destination attributes indicators will be used as an independent variable in their effect on the dependent variable is the length of stay (LOS) in this study.
The research results found that length of stay in the scope of tourism is positively influenced by several factors such as demographics, previous visits, as well as destination quality and attributes (Barros \& Machado, 2010) and to promote tourism revenue based on the tourists' length of stay the stakeholders need to diversify tourism activities to encourage business visitors and those on leisure and recreation to stay longer (Kazuzuru, 2014). On the other hand, the more research result found in the opposite way that the length of stay of tourists negative and insignificant effect on local revenue (Suastika \& Yasa, 2017), and there is no significant effect between perceptions about destination attractiveness to the length of stay of tourists (Wibowo, 2012).

Those gaps in previous research results encourage the authors to explore more research in line with the influence of destination attributes on tourists' length of stay. It is believed that the result of this research will be significantly contributing to identifying which quality of attributes considered as good conditions and the quality of attributes that need to be improved.

\section{LITERATURE REVIEW}

\section{Destination Attributes}

The Indonesian tourism industry performance was not sufficient to contribute to economic development. It was found that Indonesian hotels are lacking in good supply chain activities (Sutono, 2018). One of the most essential and influential factors of the tourism industry and 
Jurnal Bisnis dan Manajemen, Volume 22, No. 1, March 2021, p. 40-50

related elements is the destination. Destination Attributes play an important role in the economic sustainability of a destination, as stated by Diaz \& Rodriguez (2019) that a destination needs to pay attention to how the condition of its attributes and how these attributes have an attractive effect so that it can create a sustainable economic achievement. Destination Attributes have been recognized by several experts as a tool for evaluating a destination. Some experts express their opinions related to the elements contained in the concept of Destination Attributes.

The variables such as age, race, the fact that a person has visited a destination before, their level of education, motivation, and cultural values strongly influence a destination's image. It shows the relationship between the tourist characteristic and the destination image (Trisnawati, 2020).

Ritchie \& Crouch explained that Destination Attributes are Physical Attributes, especially in their role in building Destination Image (Ritchie \& Crouch, 2003). However, Echtner \& Ritchie emphasizes that Destination Attributes are not only about physical attributes, but also psychological attributes (Echtner \& Ritchie, 2003). Finally, Cooper et al., Complete Echtner $\&$ Ritchie's destination attribute theory by adding conative attributes that focus on aspects of behavior \& attitude (Cooper et al., 2018). In 2014, Hyeong paraphrased the destination attributes concepts from several experts, including Dwyer et al., and Echtner \& Ritchie became a newer and more applicable destination attributes concept. In his concept, Kim divides the attributes of a destination into 10 sections based on its use to measure the Memorable Tourism Experience (MTE) (Kim, 2014). In the end, Kim's concept was used because the concept was considered newer and more relevant to the research locus.

By the theory put forward by Hyeong (2014), 10 attributes need to be completed by a destination, including infrastructure, superstructure, accessibility, local culture/history, physiography, activities/events, destination management, service quality, hospitality, and place attachment.

\section{Tourists' Length of Stay}

The duration of a tourist's stay becomes important and essential, this is related to the longer tourists stay the wider the scope of exploring a destination, resulting in greater and more diverse effects. However, in assessing the length of stay tourists need to use specific variables and not too many because if research uses too many variables it will be difficult to imply the results on the destination and its policies (Barros \& Machado, 2010).

In connection with that, Barros and Machado explained that in examining the length of stay of tourists, several covariate variables that were considered influential could be used such as a) the budget; b) destination attributes; c) sociodemographic character; d) the previous visit; e) temporal constraint; and f) frequency of traveling. 
Jurnal Bisnis dan Manajemen, Volume 22, No. 1, March 2021, p. 40-50

From the explanation, it is known that one of the variables related to how long tourists stay at a destination is Destination Attributes. This is reinforced by the statement of Jani et al. (2009) that tourist destinations consist of multidestination travel attributes which include environmental (physical) attributes and service attributes that encourage tourists to visit and stay longer. Thus, it can be ascertained that the relationship between the condition of the attributes of a destination to the length of stay of tourists in the destination is quite large.

\section{METHODS}

In this study, the research design applied was a type of survey research design (cross-sectional). Sugiyono (2011) explained that survey research design is a type of research design that works by collecting homogeneous data from a sample of a population using a questionnaire so that the findings obtained from an event and the relationship between variables independent variable is Destination Attributes which contains 10 sub-variables while the dependent variable is the Length of Tourist Stay with a single subvariable. The purpose of using survey research designs is to get a detailed picture of the background, as well as the characteristics that characterize a cause or event that is general.

This research used a descriptive method with a quantitative approach to get a detailed description of the actual condition of the Kebumen destination attributes and its effect on the length of stay of tourists from the measured sub-variables.

The population in this study are all tourists who have visited the tourist attractions in Kebumen. Meanwhile, sampling using a simple random sampling technique which is based on homogeneous data. The number of samples targeted is 100 tourists who have visited tourist attractions in Kebumen, especially Menganti Beach, Van Der Wijck Fort, and Jatijajar Cave. Sampling is given a limit for tourists who have a visiting period of the last two years. Data analysis techniques include classical assumption and hypothesis testing using simple linear regression analysis techniques through computer applications (SPSS and Ms. Excel).

\section{RESULTS}

Based on the results of data analysis and discussion, several points were obtained, including that, in general, the actual condition of destination attributes was good. This is evidenced by the responses of respondents who showed a positive attitude, especially towards the superstructure, accessibility, physiography, quality of service, and hospitality attributes with data acquisition of $>50 \%$ expressed the attitude of agreeing and strongly agreeing (positive).

The second point is that some attributes are considered to be good enough, with some notes that need to be underlined. The attributes are infrastructure attributes that still need to be improved, especially in terms of infrastructure modernization and information provision in 
Jurnal Bisnis dan Manajemen, Volume 22, No. 1, March 2021, p. 40-50

digital portals. Also, it is necessary to improve the cleanliness management system as a form of improving the attributes of destination management.

Finally, the three remaining attributes are considered not good enough; this is based on the response of respondents $>50 \%$ who expressed a negative attitude (disagree and strongly disagree) towards the proposed indicators. Further transformation and analysis of the three attributes are needed, namely local cultural attributes, activities/events, and place attachments. In the local cultural/historical attributes, additional programs are needed in each of the tourist attractions that accommodate tourists' desire to learn or experience firsthand the philosophical/historical way of life / cultural uniqueness of residents. In the event/event attribute, although the activity indicators outside of daily activities are already good, it is necessary to increase the quality and increase the number of events, especially in each tourist attraction. Finally, there needs to be an analysis of how the motivation to visit tourists, especially for local tourists, so it is known why tourists are not interested in cultural or ethnic ties with Kebumen even though geographically, the domicile is still related.

By data released by the Kebumen Disporapar in 2019, that the record of the length of stay of tourists in Kebumen is indeed still very low, with a magnitude of the time duration of 0.51 days in 2017 and 0.54 in 2018. Data obtained from respondents in this study also showed that the majority of respondents visited Kebumen within $<24$ hours.

However, what needs to be noted is that more than $50 \%$ of respondents claimed to want to stay longer in Kebumen on their next visit; even the majority said they could confirm this.

Simple regression analysis that has been carried out on 100 respondents' answers yields an equation that can be drawn from the table below:

Table 1. Regression Analysis Equation Coefficients $^{\mathrm{a}}$

\begin{tabular}{|c|c|c|c|c|c|}
\hline \multicolumn{6}{|c|}{ Coefficients $^{\mathrm{a}}$} \\
\hline \multirow[b]{2}{*}{ Model } & \multicolumn{2}{|c|}{$\begin{array}{c}\text { Unstandardized } \\
\text { Coefficients } \\
\text { Std. }\end{array}$} & $\begin{array}{l}\text { Standardized } \\
\text { Coefficients }\end{array}$ & \multirow[b]{2}{*}{$\mathbf{t}$} & \multirow[b]{2}{*}{ Sig. } \\
\hline & B & Error & Beta & & \\
\hline 1 (Constant) & .870 & .304 & & 2.859 & .005 \\
\hline $\begin{array}{l}\text { Destination } \\
\text { Attributes }\end{array}$ & .585 & .090 & .548 & 6.488 & .000 \\
\hline
\end{tabular}

From the test results of the influence of the two variables through simple linear regression analysis techniques, the results show that destination attributes have a positive effect on the length of stay of tourists with a regression equation $\mathrm{Y}=0.870+0.585$, which means that every $1 \%$ addition to the destination attributes variable will increase the value variable length of stay of tourists of 0.585 .

Table 2. Hypothesis test

Coefficients $^{\mathrm{a}}$

\begin{tabular}{|c|c|c|c|c|c|}
\hline Model & $\begin{array}{r}\text { Unsta } \\
\text { Coe } \\
\text { B }\end{array}$ & $\begin{array}{l}\text { dardized } \\
\text { icients } \\
\text { Std. } \\
\text { Error }\end{array}$ & $\begin{array}{c}\text { Standardized } \\
\text { Coefficients } \\
\text { Beta }\end{array}$ & $\mathbf{t}$ & Sig. \\
\hline 1 (Constant) & .870 & .304 & & 2.859 & .005 \\
\hline $\begin{array}{l}\text { Destination } \\
\text { Attributes }\end{array}$ & .585 & .090 & .548 & 6.488 & .000 \\
\hline
\end{tabular}


Jurnal Bisnis dan Manajemen, Volume 22, No. 1, March 2021, p. 40-50

In testing the hypothesis through a comparison test technique $t$ value calculated with the value of $t$ table obtained results that $t$ count compared to $t$ table of 6.488: 1.661 which means $\mathrm{H}_{\mathrm{a}}$ hypothesis which states that there is a significant influence between destination attributes with the length of stay of tourists in Kebumen Regency accepted, vice versa $\mathrm{H}_{\mathrm{o}}$ who stated that there was no significant influence between destination attributes and the length of stay of tourists in Kebumen Regency was rejected.

\section{Table 3. Determinacy Coefficient}

\begin{tabular}{|l|c|c|c|c|}
\hline Model & R & $\begin{array}{c}\text { R } \\
\text { Square }\end{array}$ & $\begin{array}{c}\text { Adjusted R } \\
\text { Square }\end{array}$ & $\begin{array}{c}\text { Std. Error of } \\
\text { the Estimate }\end{array}$ \\
\hline 1 & $.828^{\mathrm{a}}$ & .686 & .583 & .59862 \\
\hline
\end{tabular}

a. Predictors: (Constant), Destination Attributes

Source: Processed data, 2020

Through the analysis of the coefficient of determination, the results show that the destination attribute variable has a significant influence on the length of stay of tourists in Kebumen, which is $68.6 \%$ according to the value of $\mathrm{R}$ Square $\left(\mathrm{R}^{2}\right)$ obtained.

\section{DISCUSSION}

The actual condition of destination attributes in Kebumen is generally quite good. In the infrastructure attribute, public facilities and interpretation boards are available with a unique and attractive design. However, what remains to be noted is that there needs to be a modernization of these facilities, such as the use of a digital technology-based ticketing system, a modern sanitation system, the use of environmentally friendly sources of labor, and the provision of information on an online portal that is more attractive and informative. The policy was included in the 2017-2025 RIPPARDA Kebumen and it is stated that these things have become the focus of program development and making. Nonetheless, there is still no-good result in reality.

Whereas, in the superstructure attribute, the condition of each indicator such as the uniqueness of the architecture in the tourist attraction, the availability of distinctive culinary delights, and the availability of look-out posts are considered good by tourists. This can be seen in several tourist attractions such as Suwuk Beach, Menganti Beach, and Jatijajar Cave which provide these three things, even in good condition. This can be seen in the reviews provided by travelers on digital review portals such as Tripadvisor.

Another attribute is accessibility, both the accessibility towards destinations (Kebumen) and the accessibility inside destinations. By the responses of respondents who stated that they had no difficulty reaching the existing tourist attractions even though most of the favorite tourist attractions such as Menganti Beach, Jatijajar Cave, and Suwuk Beach are quite far from the center of Kebumen City (> $30 \mathrm{~km}$ ). However, considering that the road conditions are already good so tourists are getting easier, faster, and more comfortable in reaching tourist attractions, especially in the southern part of Kebumen. 
Jurnal Bisnis dan Manajemen, Volume 22, No. 1, March 2021, p. 40-50

Unfortunately, the local cultural/historical attributes have not received a positive response from respondents. This is because there are no special programs provided by the manager of tourist attractions for tourists to experience local culture/history belonging to residents. If tourists can experience/learn about local culture/history, automatically the duration of their stay will be even longer.

One of the attributes that received a very positive response from respondents is the physiographic attribute. Respondents admit that they strongly agree if the natural and landscape conditions in the tourist attractions in Kebumen are very good. Not only that, but several tourist attractions are also equipped with attractive ecological diversity zones, such as the zoo in Jembangan Water Area, Butterfly Park in Krakal Hot Springs, and Pine Forest on Bukit Pentulu Indah. This is due to the commitment of the Kebumen Regency Government through the Tree Planting Program (PUSPA) organized by the Disporapar Kebumen for the sake of preserving nature around the tourist attractions in Kebumen. Moreover, the Kebumen Regency Government has also made a forest tourism development program that is equipped with various kinds of rare flora in several tourist attractions in Kebumen.

In the event attribute, the respondent's response to the event indicator is still not good enough. This is based on the opinion of respondents who feel that there are still no events or festivals that have been found or worth waiting for. The Kebumen Regency Government has arranged several large events both held in the city center and each tourist attraction. Therefore, it is necessary to have further studies on this issue. As for the activity indicators provided in each tourist attraction, respondents responded well and they claimed to have discovered new experiences from these activities.

The next attribute is destination management. In this attribute, all indicators (traffic system, safety, cleanliness, and the concept of tourist attraction) are good enough. However, the score for the hygiene indicator is the lowest score among the other three indicators. This indicates that there needs to be more attentive to the waste management system and regulations for tourists. This is reinforced by several online articles that discuss the lack of good waste management in tourist attractions in Kebumen. As reported in the Jayantaranews.com article published on July 25, 2019, the condition of the beaches in the south of Kebumen, especially Petanahan Beach, is quite dirty and shabby, so that it disappoints tourists.

In the service quality attribute, most respondents claim to have received hospitality and excellent service (service excellence) and can propose customized services from officers in tourist attractions. This needs to be appreciated and should be maintained because tourism is a service sector, tourists should get the best service from the manager when traveling so that tourists feel comfortable and want to stay even longer.

As the service quality attribute, the respondent also showed very good responses on 
Jurnal Bisnis dan Manajemen, Volume 22, No. 1, March 2021, p. 40-50

the hospitality attribute. Tourists claim that local people are friendly to them, do not hesitate to assist, and can provide clear information when tourists ask about certain destinations or tourist attractions.

Finally, the place attachment attribute. What is meant by this attribute is whether the motive for visiting tourists is based on the relationship between these tourists and Kebumen, both ethnically, culturally and their interest in the tourist attraction that tourists are interested in. Although most tourists are domestic, most of them admit that visiting Kebumen is not based on this connection.

Meanwhile, from the perspective of the length of stay of the tourists themselves, most of the respondents admitted that they did not visit Kebumen for more than 24 hours. Most of them admitted that they only stopped in Kebumen because it was located on the main route from Bandung and Jakarta to Yogyakarta. However, it should be noted that according to the respondents' responses, it can be seen that they want to stay longer when they return; most of the respondents even confirm this. This means that overall tourist perceptions of the condition of the destination attributes in Kebumen are good and make tourists want to visit longer one day.

The findings show that destination attributes consisting of infrastructure, superstructure, accessibility, local culture/history, physiography, events, destination management, service quality, hospitality, and place attachments influence the length of stay of tourists in the Kebumen
Regency. The results of this study support the findings of Jani, Jang \& Hwang (2009) who found that one of the factors that tourists consider staying longer in a destination is due to the attributes of the destination. Tourists consider that the destination attributes in Kebumen Regency still need improvement so that this has a direct impact on the length of their stay in the Kebumen Regency which is only brief.

\section{CONCLUSION AND SUGGESTION}

The condition of destination attributes in the Kebumen Regency is good, especially for the superstructure, accessibility, physiography, service quality, and hospitality attributes. For infrastructure and destination management attributes, it is quite good, but it needs to be improved in several indicators. As for local culture attributes, activities/events and place attachments are not good enough and need special attention. For the length of stay, most tourists visit Kebumen with a duration of $<24$ hours. However, they did not mind staying longer on their next visit, some of whom could even confirm that. Destination attributes have proven to have a significant positive effect on the length of stay of tourists in Kebumen.

For stakeholders who work in tourist areas, it is necessary to develop types of cultural attractions in each tourist attraction so that tourists have the opportunity to know experience about the way of life/philosophical history or cultural uniqueness of local residents. Besides, it is also necessary to add the organization of 
Jurnal Bisnis dan Manajemen, Volume 22, No. 1, March 2021, p. 40-50

special events at tourist attractions or to maximize events so that tourists have other activity options.

To explore more research, it is also necessary to strengthen the attributes considered in good condition such as infrastructure, superstructure, accessibility, physiography, destination management, service quality, and hospitality attributes to strengthen the quality of those attributes. On the other hand, it is also required to improve more research in line with the quality of the activities or events, local culture, and place attachments.

\section{REFERENCES}

Barros, C. P., \& Machado, L. P. (2010). The length of stay in tourism. Annals of Tourism Research, 37(3), 692-706. https://doi.org/10.1016/j.annals.2009.12.00 5

BPS Kabupaten Kebumen. (2019). Kabupaten Kebumen Dalam Angka Tahun 2019. https://doi.org/33050.1901

Bupati Kebumen. (2017). Peraturan Daerah Kabupaten Kebumen Nomor 7 Tahun 2017 Tentang Rencana Induk Pembangunan Kepariwisataan Kabupaten Kebumen Tahun 2017-2025.

Chahal, H., \& Devi, A. (2015). Destination Attributes and Destination Image Relationship in Volatile Tourist Destination: Role of Perceived Risk. Metamorphosis: A Journal of Management Research, 14(2), 1-19. https://doi.org/10.1177/097262252015020 3

Cooper, C., Volo, S., Gartner, W., Scott, N., \& Dwyer, L. (2018). Economics of Tourism. The SAGE Handbook of Tourism Management: Theories, Concepts, and Disciplinary Approaches to Tourism, 173189. https://doi.org/10.4135/9781526461452.n1 1

Echtner, C., \& Ritchie, J. (2003). The meaning and measurement of the destination image. Journal of Tourism Studies, 2(2), 2-12.

Gössling, S., Scott, D., \& Hall, C. M. (2018). Global trends in length of stay: implications for destination management and climate change. Journal of Sustainable Tourism, 26(12), 2087-2101. https://doi.org/10.1080/09669582.2018.15 29771

Jani, D., Jang, C.-I., \& Hwang, Y.-H. (2009). Differential effects of tourism resources on the attractiveness of destination bundles. International Journal of Tourism Sciences. International Journal of Tourism Science, 9(1).

Kazuzuru, B. (2014). Determinants of Tourist Length of Stay in Tanzania. International Journal of Business and Social Science, Vol. 5, No. 9(1).

Hyeong, K. J. (2014). The antecedents of memorable tourism experiences: The development of a scale to measure the destination attributes associated with memorable experiences. Tourism Management, 44, 34-45. https://doi.org/10.1016/j.tourman.2014.02. 007

Ritchie, B., \& Crouch, G. I. (2003). The Competitive Destination: A Sustainable Tourism Perspective. CABI International.

Rodriguez-Diaz, M., \& Espino-Rodriguez, T. F. (2019). Tourism Destination Management. MDPI.

Santos, G. E. de O., Ramos, V., \& ReyMaquieira, J. (2015). Length of Stay at Multiple Destinations of Tourism Trips in Brazil. Journal of Travel Research, 54(6), 788-800. https://doi.org/10.1177/004728751453237 0

Suastika \& Yasa, Pengaruh Jumlah Kunjungan Wisatawan Lama Tinggal Wisatawan dan Tingkat Hunian Hotel Terhadap Pendapatan Asli Daerah dan Kesehjateraan Masyarakat pada Kabupaten /Kota di Provinsi Bali, E-Jurnal EP Unud, 6[7] : 1332-1363, ISSN: 2303-0178 
Jurnal Bisnis dan Manajemen, Volume 22, No. 1, March 2021, p. 40-50

Sutono, A. (2018). Supply chain management: implementation issues and research opportunities in the tourism industry. Uncertain Supply Chain Management, 427438.

Sugiyono. (2011). Metodologi Penelitian, Kuantitatif, Kualitatif dan $R \& D$. Alfabeta.

Thrane, C., \& Farstad, E. (2012). Tourists' length of stay: The case of international summer visitors to Norway. Tourism Economics, 18(5), 1069-1082. https://doi.org/10.5367/te.2012.0158

Trisnawati Sule, E., (2020). Effect of Tourist Characteristics and Resources on Image: Study of Ciletuh Geodiversity Area Sukabumi. Jurnal Bisnis dan Manajemen., Volume 21, No. 2, September 2020, p.129143

Uysal, M., Perdue, R., \& Sirgy, M. J. (2012). Enhancing the Lives of Tourists and Residents of Host Communities. Handbook of Tourism and Quality-of-Life Research, 1 . https://doi.org/10.1007/978-94-007-2288-0

World Tourism Organization (UNWTO). (2019). Yearbook of Tourism Statistics, Data 2013 - 2017, $2019 \quad$ Edition. https://doi.org/https ://doi.org/10.18111/97 89284420414

Detik.com. (2019, 23 Desember). Kebumen Termiskin di Jateng Tahun 2019, Begini Yang Akan Dilakukan Pemkab. Diakses pada 25 Februari 2020, dari https://news.detik.com/berita-jawatengah/d-4833357/kebumen-termiskin-dijateng-tahun-2019-ini-yang-akandilakukan-pemkab

Wibowo, N.B.P., (2012). Pengaruh Motivasi Wisata, Persepsi tentang Daya Tarik dan Kualitas Pelayanan Terhadap Lama Tinggal Wisatawan di Provinsi DIY, Jurnal Nasional Pariwisata, Vol. 4, No. 1, (25-34)

ISSN: 1411-9862 